Plennary Session

\title{
Praktik Arsitek dalam Pencarian Keseimbangan Baru
}

\author{
Suwardana Winata \\ Ikatan Arsitek Indonesia Nasional, Badan Pendidikan, Jakarta, Indonesia \\ Jakarta Design Center 1t7, J1 Jend.Gatot Subroto Kav 53, Jakarta 10260 \\ Email: danarsitek@gmail.com
}

\begin{abstract}
Abstrak
Epidemi Covid 19 menjadikan manusia harus melakukan retropseksi tentang berbagai kesehariannya, salah satunya adalah bagaimana arsitek bekerja di dalam praktik keprofesiannya. Epidemi ini membuat arsitek harus melakukan tinjauan kembali seperti tentang program ruang, proses kerja maupun berkehidupan dalam keseharian. Perubahaan tempat kerja adalah hal yang pertama kali terkena dampaknya. Hal lain yang terberat dalam praktik arsitek adalah koordinasi pekerjaan baik di studio maupun di proyek, karena itu diperlukan berbagai metode kolaborasi dan "perpanjangan" indra, sehingga pekerjaan dapat dilakukan terus tanpa terganggu. Penggunaan sistem dan peralatan digital, merupakan alternatif yang menjadi jembatan penghubung antara para stakeholder dan pelaku pekerjaan. Dampak dari sistem ini perlu diantisipasi, karena ada permasalahan dan evaluasi harus dilakukan secara fisik atau perlu beberapa orang untuk mengerjakannya. Pemilihan metode dan peralatan untuk operational praktik arsitek menjadi hal penting sehingga pembiayaan dan efisiensi kerja dapat optimum. Studio fisik berganti menjadi kolaboratif studio dalam bentuk digital seperti Pemodelan Informasi Bangunan (BIM). Penggunaan berbagai alat untuk digital input menjadi pilihan sehingga dapat meminimalisir pertemuan serta mengurangi hambatan ruang dan waktu. Kodifikasi dan pemrograman menjadi bahasa baru bagi Arsitek yang harus dipelajari. Epidemi ini membuat disrupsi di keprofesian menjadi nyata dan bukan wacana lagi, kreativitas dan kolaborasi adalah hal penting untuk dapat bertahan hidup.
\end{abstract}

Kata kunci: kolaborasi, BIM, epidemi, disrupsi, digital.

\begin{abstract}
Title: Architect Practice in Search of Balance in New Norm

Epidemic Covid 19 enforce us to retrospect our everdayness living, including how architects do for living and for the architectural practice. These condition makes some re-adjustement in architectural program, in some level must renovate totally. The biggest problem in architect profession is the project coordination, because social distancing and large number of meeting member must reduced to minimal level. This condition pushs architects to review their working process in studio and on the projects field. Physical studio is no longer a good place to collaborate and must transform into the digital studio. Digital system become a bridge to connect between stakeholders and the architects. Digital tools and method becoming an extention tools for our eyes and sense. Digital methods and practices suddenly become a daily activities for every level in architecture firms, such as Big Data. The colabortive works in digital format become important, one of them is Building Information Modelling, works as collabortive tools in virtual digital studio. The coding and the scripting are the next language for architect must learn, beside the architecture itself. Within the epidemic, disruption of profession is not a discourse anymore, but a fact that must commenced. Creativity and colaborative is the survival tools in today harsh life.
\end{abstract}

Keywords: epidemic collaboration, BIM, disruption, digital. 
Ketika tulisan ini ditulis, epidemi Covid 19 baru berjalan delapan bulan dan seluruh bumi sudah terkena dampaknya. Tulisan ini akan berbicara profesi Arsitek di kemudian hari di Indonesia.

\section{Pendahuluan}

Epidemi Covid 19, adalah epidemi yang menyebabkan manusia harus meredefinisi ulang arti hubungan sosial dan budaya manusia terutama terkait dengan hubungan fisik (physical contact) termasuk di dalamnya proses kerja dan organisasi kerja. Perubahaan ini sangat drastis dan cepat yang membuat berbagai hubungan pekerjaan harus melakukan revolusi, bila tidak sistem perekonomian di semua skala akan bermasalah.

Belajar dari the Great Depression 1931-1936, pelaksanaan proyek seperti proyek Hoover Dam di Nevada dan proyek infrastruktur lainnya serta pelaksanaan ekonomi kreatif (film, arsitektur dan sebagainya) mampu menyerap tenaga kerja secara besar-besaran termasuk Arsitektur yang menjadi motor penggerak ekonomi negara. Arsitektur sebagai bidang pekerjaan yang memiliki dua dunia, di dalam studio dan di lapangan, serta memiliki hubungan organisasi yang sifatnya multidisipliner dan interdisipliner serta multistakeholders menyebabkan pekerjaan arsitektur memiliki tingkat kompleksitas sangat tinggi sehingga oleh pemerintah dianggap sebagai bidang pekerjaan yang harus dipertahankan (strategis) karena serapan tenaga kerja yang besar yang dapat menjadi motor penggerak ekonomi yang lebih besar.

Profesi Arsitek berperan penting tidak hanya sebagai perancang, arsitek juga berperan aktif sebagai agen "penggerak", sehingga perlu berinisiatif menghadapi perubahaan dan juga disrupsi dari setiap pergerakkan zaman termasuk new normal atau lebih tepat norma baru (new norm).

\section{Posisi Arsitek, Arsitektur dan Norma Baru}

Sebenarnya apakah dampak dari new normal ini? Paradigma tentang new normal dengan social distancing, membuat hal yang terpenting dari kehidupan manusia yaitu kehidupan sosial secara fisik menjadi terganggu. Penggunaan masker setiap saat dan limitasi persentuhan fisik seperti bersalaman menjadi hal baru yang dilakukan setiap hari dan hal ini menimbulkan norma baru dalam kehidupan manusia. Pertemuan jumlah besar dengan pemusatan manusia di batasi bahkan dilarang, hal ini termasuk juga penggunaan kantor, sekolah dan supermarket. Pembatasan sosial juga berdampak besar terhadap bisnis hotel, restoran serta tempat hiburan dan turunannya dikarenakan limitasi jumlah pengunjung. Kondisi ini merupakan hal dilematis, karena permasalahan waktu dan memberikan dampak terhadap ruang yang merupakan ranah arsitektur dan perencana spasial. Apakah akan permanen atau sementara waktu dengan durasi yang lama atau pendek atau akankah berulang. Untuk jangka waktu pendek, berbagai saran dan bentuk disain diajukan sebagai temporary space. Namun bila kondisi ini 
diposisikan secara permanen, maka diperlukan tinjauan ulang secara menyeluruh terutama terhadap perencanan progam arsitektural dan aspek perancangan.

Saat ini, ketika tulisan ini ditulis, secara perhitungan ekonomi, diprediksikan secara perlahan Indonesia akan memasuki babak resesi (diprediksikan dimulai pada kuartal ke tiga atau sekitar bulan September 2020), namun hal ini dapat di hindarkan bila ada motor penggerak ekonomi yang memiliki kekuatan besar, salah satunya adalah dunia konstruksi. Dunia konstruksi menyerap tenaga kerja yang sangat banyak, variasi pekerja dan professional yang terlibat juga pengeluaran untuk belanja yang besar, sehingga diharapkan dapat mengembalikan daya beli masyarakat dan pada akhirnya menggerakan sektor ekonomi lainnya.

Sebagai salah satu pemimpin dalam dunia konstruksi, para arsitek perlu tetap secara positif melakukan pekerjaannya dan bahkan dengan kreativitasnya mampu menciptakan pekerjaan baru. Langkah-langkah yang perlu dilakukan para arsitek yaitu perlu melakukan retrospeksi apa yang sudah dilakukan dan kemudian melakukan rebuilding dengan konteks yang mungkin terjadi di masa depan. Rebuilding dalam waktu dekat yaitu perlu dilakukan meninjau ulang proses berarsitektur, hal ini terutama pada studio dan pekerjaan di lapangan dan juga bisnis arsitektur. Rebuilding untuk jangka panjang yang perlu dilakukan arsitek yaitu melakukan introspeksi terhadap berbagai rancangan di berbagai building types untuk mengantisiapsi potensi pandemi baru. Selain itu perlu membangun empati dengan mengajak para stakeholder dari hulu sampai dengan hilir, yang terlibat dalam bisnis arsitektur seperti para pendidik arsitektur, para developer, para building manager, para investor dan para pengguna tentunya, agar secara bersama-sama menyadari pentingnya proses desain, seperti arsitektural preprogramming, perencanaan design dan perancangan arsitektural serta konstruksi yang melihat tidak hanya bangunansebagai bentuk akan tetapi lingkungan sekitarnya termasuk proses bersosialiasi.

\section{Masa Depan Berarsitektur}

Ketika epidemi ini muncul, kondisi dunia sedang mengalami disrupsi, dimana banyak hal terkait dengan ekonomi sedang dalam kondisi melakukan evolusi menuju industri 4.0. Salah satu isu besar dalam disrupsi adalah persoalan ketenagakerjaan termasuk keprofesian. Banyak profesi di era disrupsi dipertanyakan ulang posisinya dalam ranah kehidupan manusia khususnya terkait dengan ekonomi. Hal ini termasuk juga dengan profesi Arsitek dianggap akan menjadi profesi yang archaic. Profesi Arsitek dianggap melakukan pekerjaan yang dapat digantikan oleh aplikasi atau kemudian dengan kecerdasan buatan (artificial inteligence).

Disrupsi di bidang Arsitektur sebenarnya mulai terjadi di akhir 90an, ketika benih-benih 3D simulasi mulai dikembangkan untuk perfilman yang kemudian berkembang menjadi BIM (Building Information Modelling), parametric dan coding, termasuk akhir-akhir ini teknologi micro robotic mulai masuk ke dalam proses keseharian berarsitektur dengan berbagai tujuan, salah satunya menciptakan posibilitas new form maupun efisiensi kerja. 


\section{Retrospeksi Peran Arsitektur}

Semua Arsitek maupun pengajar arsitektur tentunya telah mengetahui bahwa Arsitektur diciptakan untuk menyelesaikan masalah terkait dengan spasial dan manusia yang beraktivitas di dalamnya, dengan memperhatikan usaha melindungi, memperhatikan kesehatan dan meningkatkan kesejahteraan penggunanya (health, safety and walfare). Arsitektur juga dipercayai menjadi agen perubahaan bagi masyarakat yang menggunakannya.

Sejak peradaban Mesir, China dan Jawa yang berkiprah pada bentuk dan simbol, kemudian berubah meruang pada peradaban Yunani dan Romawi dengan karya arsitektur seperti Parthenon dan Pantheon, sampai dengan karya keagungan pada zaman Gothic dan Renaissance, Arsitektur secara rancangan maupun keteknikan (konstruksi) hampir tidak mengalami perubahaan yang signifikan. Renaisance dan Gothic adalah masa keemasan arsitektur dunia, namun setelah itu terjadi stagnasi, yang ada adalah pengulangan terus menerus sampai kemudian muncul Arsitektur Modern.

Setelah Arsitektur Modern, kembali arsitektur mengalami stagnasi, perancangan hanya merupakan pengulangan dan refurbishment sampai kemudian teknologi informasi (computing) merambah kedalam perancangan arsitektur. Penggunaan teknologi informasi secara ekstensif semakin dikenal berkat karya Eisenman dan Gehry, yang membuat terobosan pada hal-hal yang dulunya hanya berupa imaginasi, namun dengan bantuan teknologi informasi menjadi kenyataan.

Kebutuhan teknologi informasi ini semakin dipercepat dan meluas karena kebutuhan Arsitektur terus meningkat yang berjalan seiring dengan kemajuan ekonomi. Arsitektur bertansformasi menggunakan bahasa "lain" ketika berhadapan dengan ekonomi, termasuk juga sistem dan teknologi yang mengiringi arsitektur. Kata "indah" menjadi "efisiensi" (form follows finance), kata "kekuatan" diganti dengan "keberlanjutan (sebagai sistem)", kata "utilitas" berganti dengan "operative", "order" menjadi "management" dan istilah-istilah lain yang mungkin tidak dipelajari di Pendidikan Arsitektur di kampus.

Kreativitas para arsitek dalam melihat pergerakkan kultur masyarakat yang saat in bergantung dengan teknologi. Social distancing akibat epidemi membuat berbagai program arsitektural dipertanyakan. Institusi yang dulunya rigid dan sangat dominan, dipertanyakan kembali, seperti sekolah, terutama terkait dengan fisik sekolah (gedung). Peralihan program dari yang sangat rigid (kelas, limited) menjadi fleksibel (waktu, jumlah dan tempat). Kelas yang dulu ditempatkan, sebagai gedung sekolah, ketika harus school from homellearning from home menjadi bebas di mana saja selama terkoneksi dengan internet dan laptop. Jumlah siswa yang dulu dibatasi kemudian menjadi bebas karena hilangnya batas "dinding kelas". Institusi sekolah kemudian mendadak dipertanyakan keberadaanya termasuk juga program arsitektural yang menyertainya yaitu sekolah. Gedung sekolah yang menjadi penanda atau simbol mendadak seolaholah hilang. Siapa pun dapat belajar apa pun dan di mana pun menjadi istilah penting, ketika semua beralih kedalam ruang kelas virtual di media internet, dan seolah-olah institusi sekolah hanya berperan sebagai administrator, sehingga bila 
kondisi ini terus terjadi, maka arsitektur gedung sekolah akan dipertanyakan kembali.

Ketika epidemi Covid 19 ini terjadi, berbagai "pergeseran" mendadak terjadi. Faktor sosial-budaya yang paling terasa dampaknya, yang membuat berbagai hal dalam arsitektur dipertanyakan kembali, berbagai kebiasaan hidup seperti bekerja, berbelanja dan bersekolah dipertanyakan ulang keberadaannya termasuk bangunan yang menaunginya serta faktor ekonomi yang juga memberikan dampak terhadap daya beli, salah satunya berdampak terhadap dunia konstruksi khususnya arsitektur yang bergerak di sektor pengembangan properti. Namun "pergeseran" ini (atau dikenal dengan disrupsi) sebenarnya sudah terjadi. Namun karena epidemi, maka kondisi ini semakin dipercepat bahkan diminta untuk melompat. Retropseksi terhadap berbagai program konvensional perlu dicermati, akankah menjadi program baru atau merupakan penyederhanaan atau penggabungan program-program yang sudah ada. Refurbishment program juga menjadi masalah krusial untuk jangka panjang. Stagnasi ekonomi dapat menyebabkan bangunan ditinggalkan karena kekurangan tenant sehingga perlu mencari hal-hal baru sehingga bangunan yang ditinggalkan tidak menjadi sia-sia.

\section{Retrospeksi Peran Arsitek}

Kontribusi arsitek atas perannya pada pembentukkan lingkungan buatan, membuat profesi arsitek harus berkali-kali melakukan introspeksi terhadap posisinya. Pada awal kebudayaan, arsitek berperan sebagai agen pembangunan lingkungan (environmental builder), kemudian kebudayaan semakin maju dan semakin sadar lingkungan, ditambahkan perannya sebagai agen penjaga lingkungan (environmental guardian) dan saat ini (sebelum epidemi), ketika lingkungan (bumi) mulai mengalami "kejenuhan", "kelelahan" dan "penuaan" peran arsitek ditambah lagi sebagai agen penyelaras lingkungan (environmental coordinator). Peran sebagai penyelaras lingkungan tidak terlepas dari sifat arsitek yang harus "menciptakan" kondisi kebersamaan (coexistence) terhadap yang lama dan baru dalam berbagai bentuknya (contohnya reality - virtual reality - hypereality, private - share space - public, territory - bluring - share). Arsitek berperan dalam menciptakan kebersamaan ini, terutama dalam penterjemahaan kultur sosial baru kedalam bentuk atau spasial dalam arsitektur. Akomodasi berbagai kepentingan sangatlah penting sehingga setiap kepentingan dapat berjalan secara selaras, walaupun dalam kondisi seperti pandemi ini. Arsitek memiliki peran dalam "eksperimen" sosial dan budaya masyarakat. Perancangan plaza besar atau park movement merupakan gagasan para perancang dan planner dalam memecahkan (atau menimbulkan) masalah sosial dan kultur masyarakat. Demikian pula tentang Mixed Use, Bigness atau Urban Kampung, yang saat ini dikembangkan oleh berbagai pengembang atau pemerintah kota di Indonesia.

Secara jangka panjang posisi Arsitek kembali dipertanyakan, karena karya arsitektur juga dipertanyakan eksistensinya. Posisi arsitek yang hanya dianggap sebagai pembangun, penjaga dan penyelaras lingkungan perlu kembali melakukan kembali introspeksi bukan hanya terhadap karya dan lingkungannya saja akan 
tetapi juga proses rancangan, pendekatan dan metode rancangan, termasuk juga sistem kerja yang dilakukan selama ini.

\section{Posisi Profesi Arsitek dalam Keseimbangan Baru}

Disrupsi dan Covid 19 merupakan dua hal yang saling "mendukung", karena dengan adanya epidemi Covid 19, yang berbagai hal yang dulunya hanya wacana, terpaksa harus dilaksanakan dengan berbagai bentuk percobaan. Gedung kantor yang saat sebelum pandemi, mulai mengalami degradasi dikarenakan disrupsi ekonomi, sehingga timbul budaya co-working atau disebut juga sharing space dengan tujuan mengutilisasi ruang-ruang yang tidak produktif, saat ini harus dipertanyakan kembali keberadaanya. Semua kantor ditutup dan mulai work from home terjadi perubahaan drastis dalam fungsi kantor, pertemuan virtual menjadi hal lumrah, bekerja secara network menjadi kebiasaan baru, tata cara bekerja juga berubah, ruang kantor berganti di ruang internet dan laptop dengan tujuan agar fungsi kantor tetap beroperasi seperti biasa. Kondisi ini masih dianggap sementara, namun bila epidemi ini berkepanjangan, tidak menutup kemungkinan budaya kantor konvensional berubah total selamanya, bahkan dalam jangka panjang, gedung-gedung kantor akan terpaksa beralih fungsi, karena tidak digunakan lagi sebagai kantor. Hal ini menjadi perhatian pemerintah, developer dan arsitek karena akan menyangkut nilai ekonomi yang tidak sedikit dan bagi arsitek sebagai konsultan.

Namun bila melihat survei dari Gensler (sebuah konsultan arstektur internasional) terkait dengan kantor di tahun 2020 di AS, bahwa hanya $12 \%$ penduduk di AS menginginkan bekerja di rumah. Hal ini memberikan angin sejuk kepada para arsitek dan para developer, karena masih diperlukan gedung-gedung kantor dan bila melihat hasil surveinya, ternyata kantor tidak hanya berperan sebagai administrasi semata melainkan juga sebagai wadah bersosialiasi (https://www.gensler.com/uploads/document/695/file/Gensler-US-Work-From-

Home-Survey-2020-Briefing-1.pdf, diakses September 2020). Sosialisasi merupakan program penting dalam menentukan produktifitas para karyawan, karena itu harus diterjemahkan menjadi spasial ketika merancang sebuah kantor.

Profesi Arsitek selain merancang untuk para kliennya untuk sebuah perubahaan, di sisi lain, arsitek juga perlu bertransformasi dalam proses operasionalnya, sehingga mutu dan kualitas rancangan tidak dikorbankan, termasuk juga kualitas hasil konstruksi yang harus selalu dikontrol. Hal ini menyebabkan perlu perubahaan dalam Standard Operating Procedure-nya (SOP), yang diakibatkan oleh social distancing, termasuk juga prilaku dalam studio.

\section{Bekerja sebagai Arsitek di Zaman Norma Baru}

Profesi arsitek dan keseharian keprofesiannnya juga mengalami disrupsi dan tibatiba harus berrevolusi karena Covid 19. Ada beberapa hal dalam keprofesian arsitek berubah drastis namun juga ada yang memang sudah dilakukan namun tidak secara ekstensif. Intergrated workgroup, virtual office, online design studio, 
integrated design system, integrated field report, shareable sources dan masih banyak istilah lain adalah sistem kerja yang sudah sering dicoba, dan semenjak Covid 19 dipaksa untuk digunakan secara ekstensif. Berbagai metode dilakukan agar proyek dapat berjalan dengan "normal". Hambatan terbesar akibat social distancing, yaitu sangat sulitnya bagi para arsitek maupun stakeholder lainnya untuk tidak bertemu, terutama terkait dengan keputusan di lapangan. Pertemuan dengan klien atau yang sifatnya presentasi dan manajemen dapat diatasi dengan melakukan pertemuan melalui "virtual war-room" dengan video conference. Kerja sama dalam Studio tetap dapat dilakukan dengan penggunaan BIM sehingga dapat dilakukan secara integrated dan simultant, sehingga selama terhubung dengan cloud maka siapapun dapat melakukan design, editing dan evaluasi. Para stakeholder dan pemilik dapat langsung berdiskusi secara live. Namun di sisi lain virtual meeting ini dapat menghambat produktivitas karena sulitnya klien untuk melihat pekerjaan dengan jelas, karena keterbatasan display dan peralatan lainnya. Teknologi VR dapat dilakukan namun tidak semua klien dapat menggunakannya dengan mudah. Teknologi 3D lainnya sangat tidak interaktif dibandingkan dengan bila menggunakan maket yang kebih WYSIWYG. Di sisi lain klien dapat dengan mudah memberikan masukan dan melakukan monitoring perubahaan rancangan selama 24 jam.

Kemudahaan-kemudahaan ini harus dibayar dengan kenaikan operational cost yang sangat membutuhkan peralatan dan bandwidth besar. Biaya ruang sewa kantor bergeser menjadi investasi peralatan dan menyewa bandwidth serta listrik. Biaya energi personal menjadi bengkak. Work from home (WFH), secara teori menyenangkan karena dapat menyelesaikan beberapa pekerjaan sekaligus, dan mengurangi birokrasi, di sisi lain kondisi ini menciptakan aturan atau mungkin gaya hidup baru.

\section{Peralatan Digital sebagai Kepanjangan Indra/Tangan Arsitek atau Pembunuh Arsitek}

Penggunaan peralatan digital pada awalnya dilakukan sebagai alat yang membantu mengurangi kesalahan, namun saat ini bertrasnformasi sebagai alat untuk menekan angka pertemuan manusia. Hal sederhana seperti pengukuran ruangan, saat ini dapat dilakukan cukup dengan 1 orang saja tentunya dengan perlengkapan seperti laser guidance, laser mapping, GPS dan tentunya jalur internet. Data akan dikumpulkan melalui laser mapping kemudian disusun ulang dalam program CAD atau lainnya. Cross check atau cross reference dapat dilakukan melalui GPS atau laser rulers, rollers dan berbagai alat yang memiliki dasar GPS dan laser.

Penggunaan drone, baik udara maupun darat, juga sangat membantu untuk melihat sisi lain yang mungkin selama ini memiliki keterbatasan secara fisik atau keterbatasan pada tingkat detil tertentu. Drone dengan tambahan alat tertentu dapat membaca (mapping) suatu wilayah atau tapak dengan akurasi tinggi, termasuk juga ke dalam tanah. Insinyur maupun arsitek dapat merekonstruksi apa saja yang ada didalam tanah maupun permukaan tanah dengan menggunakan metode reverse engineering. 
Metode ini juga digunakan untuk mencari pola atau bentuk-bentuk tertentu yang mungkin sulit dibuat atau dihitung secara matematis. Hal ini banyak digunakan sebagai jembatan analog to digital oleh para arsitek yang membuat bentuk tertentu yang kemudian dilakukan rescale sehingga dapat ditempatkan di Gedung sebagai façade misalnya. Digital mapping dengan digital input membuat data digital (wiremesh atau triangulate surface). Penggunaan 2D /3D printing secara digital to digital digunakan untuk membuat prototipenya. Pada 2D printing, teknologi pemotongan (CNC, laser cutter, water jet) maupun 3D printing sudah memiliki teknologi untuk membuat prototipe berukuran besar. 2D printing dengan teknologi saat ini dapat memotong hampir semua benda (metal, kayu, plastik, akrilik) demikian juga 3D printing dengan berbagai teknologinya (piezo, laser, ultrasonic, heated) serta didukung dengan teknologi material (ABS, paper, PU, PP, bahkan fibre cement) sudah mampu membuat sebuah rumah dengan kecepatan satu rumah perhari. Bahkan China berencana membuat gedung 11 lantai dengan menggunakan 3D printing. Bila visi ini dikembangkan bahkan para arsitek tidak perlu lagi ke proyek, karena semuanya dapat dilakukan secara jarak jauh, atau bahkan tidak perlu arsitek lagi.

\section{Scripting dan Coding sebagai Bahasa Ketiga dalam Berarsitektur}

Teknologi digital membuat arsitek (individu atau grup) dapat berbuat lebih baik secara multidisiplin bahkan crossdisiplin. Limitasinya ada di kreativitas arsitek, seperti Marcus du Sautoy dalam bukunya The Creativity Code (2019), menyebutkan bahwa kreativitas manusia tidak memiliki limitasi. Selalu berkembang dan berkembang, walaupun ada AI, kreativitas manusia berkembang dengan bahasa sendiri yang tentunya berbeda dengan AI (dan harus diingat AI dikodekan oleh manusia), kecuali manusia melebur menjadi AI atau memecahkan dirinya menjadi code seperti film Transcendence (2014).

Archicad, Revit, MAYA, Microsataion, Rhinoceros dan StudioMax adalah nama yang sudah tidak asing bagi aristek, namun tidak dengan Grasshopper, MEL's, MAXScript dan LISP, merupakan script dan coding untuk menjalankan aplikasi yang disebutkan sebelumnya. Aplikasi ini awalnya digunakan untuk berbagai kegunaan yang tidak berhubungan langsung dengan dunia arsitektur, misalnya Microstation (Bentley System) dirancang untuk para engineer membuat mesin, Maya dirancang untuk digunakan membuat animasi dan special FX pada layar lebar dan gaming. Grasshopper, digunakan untuk desain produk, bahkan Catia digunakan untuk membuat pesawat terbang.

Para arsitek melihat potensi lain dari aplikasi ini dan kemudian meminta para software engineer memodifikasi aplikasi itu untuk digunakan memecahkan masalah arsitektural. Saat ini aplikasi itu menjadi alat bantu yang sangat mumpuni terutama pada kasus-kasus bentuk atau sistem non platonik. Pengembangangan lanjutannya adalah membuat aplikasi itu "mudah" bagi para arsitek untuk melakukannya terutama di tingkat pra rencana, sehingga tidak perlu lagi para software engineering berulang kali menuliskan script-nya atau coding-nya. Bahkan menurut Mark Burry dalam bukunya Scripting Culture (2011), scripting 
atau coding itu sudah menjadi bagian dari "kebutuhan" arsitek bukan hanya untuk menciptakan bentuk yang tidak biasa (making form), namun scripting juga digunakan untuk melakukan analisis posibilitas dan kombinatori (contohnya CFD untuk sirkulasi manusia pada saat peak hour misalnya), integrasi sistem (misalnya façade, sistem penerangan dan penggunaan energi), management konstruksi (misalnya tabrakkan antara sistem terowongan MRT dengan pondasi bangunan).

Scripting dan coding menciptakan sistem otomasi yang dilakukan secara logika coding yang ditujukan sebagai otomisasi. Sistem ini dapat belajar sendiri dengan mempelajari posibilitas, perhitungan probabilitas dan melakukan penawaran pelaksanaan (offering execution) sesuai dengan konteks yang dihadapi, semakin sistem ini sering belajar maka semakin cepat putusan yang diambil dan semakin presisi, sistem ini kemudian disebut dengan kecerdasan buatan (Artificial Inteligence - AI). AI inilah yang dianggap menjadi "pembunuh" berbagai profesi termasuk arsitek. Marcus du Sautoy mengajukan suatu pemikiran tentang keberadaan AI dalam kehidupan manusia. AI dengan kemampuannya yang dapat belajar sendiri, dan sangat besar kemungkinan bahwa AI akan mengatur, mengembangkan bahkan memutuskan hal-hal yang terkait dengan kehidupan manusia.

Dahulu robot (embodiment dari AI) dianggap tidak akan pernah dapat membuat lukisan atau patung, karena karya seni dianggap intuitif dan memiliki keunikkan masing-masing sesuai dengan seniman pembuatnya. Saat sekarang, hal ini dapat dibantah dengan mudah. AI saat ini mampu membuat lukisan, patung dan artwork lainnya dengan mudah, bahkan dengan berbagai gaya pelukis. Hal ini dapat terjadi ketika manusia dapat menemukan hubungan seni dengan matematika, maka coding dapat dibuat dan kemudian, maka seni pun dapat dilakukan oleh AI.

Hal ini menyebabkan keprofesian arsitek dalam kondisi di ujung tanduk, karena arsitek merupakan sebuah profesi yang memadukan unsur seni (Art), teknologi (technology), sains (science) dan kemanusiaan (humanity). Teknologi dan seni dapat dibaca, direplika dan dikembangkan oleh AI, hanya kemanusiaan saja yang belum dilakukan. Cepat atau lambat dengan kemampuan dan kreativitas manusia, AI akan belajar tentang arsitektur dan tentunya berpikir seperti Arsitek.

Di sisi lain, menurut du Sautoy, apa yang akan dikerjakan oleh AI akan memiliki pengertian sendiri dan keunikan yang hanya dimengerti oleh AI selama kognitif manusia terus berevolusi. AI memiliki bahasa dan pengertian tersendiri yang tentunya belum tentu dimengerti oleh manusia demikan pula sebaliknya (dan mungkin manusia tidak perlu tahu). Kreativitas adalah jawaban kenapa manusia saat ini masih terus dapat bertahan hidup.

\section{Sebuah Diskusi Terbuka}

Arsitektur dalam sejarahnya dirancang dan dibangun untuk menyatakan kebesaran suatu bangsa. Profesi Arsitek dibentuk dengan tujuan untuk menjaga mutu dan kualitas rancangan bangunan serta menegakkan pertanggungjawaban rancangan ke masyarakat. Epidemi Covid 19 membangun kesadaran terhadap arsitek akan 
apa yang sudah dilakukan. Berbagai tipe bangunan harus dievaluasi baik sebagian atau menyeluruh, termasuk juga berbagai program arsitektural yang terkena dampak norma baru ini. Profesi arsitek berperan dalam mengevaluasi dan memperbaharui program arsitektural ini sehingga tidak memiliki dampak yang berkepanjangan terutama terhadap sector ekonomi.

Akibat epidemi ini, manusia dapat belajar akan satu hal penting, bahwa kehidupan manusia sangat fragile. Adapatasi merupakan salah satu solusi, namun perlu waktu agar menjadi seimbang. Berbagai aspek kehidupan, seperti sosial kultural dan ekonomi di dunia ini sedang dalam proses pencarian keseimbangan baru. Profesi Arsitek, sebagai agen penggerak sosial budaya dan ekonomi masyarakat harus melakukan adjustment baik dalam proses berarsitekturnya baik di dalam membuatnya (di dalam studio), membangunnya (di lapangan) maupun arsitekturnya itu sendiri (sebagai bangunan atau gedung).

Tinjauan ulang terhadap berbagai program arsitektur seperti kantor, sekolah, pusat perbelanjaan, mixed use dan berbagai program asitektur lainnya sangat diperlukan termasuk juga terhadap program arsitektur atau spasial dalam skala besar, seperti ratio tempat terbuka, ratio ruang kepada densitas dan hal lain, demi menjaga atau mengantisipasi bila epidemi seperti ini terulang.

Tidak hanya arsitektur atau fisik bangunan namun juga sistem dan proses kerja perlu dipertimbangkan untuk mengalami perubahaan termasuk juga dengan cara para arsitek bekerja. Penggunaan alat bantu digital maupun aplikasi memberikan perpanjangan indra arsitek dalam memonitoring, mengevaluasi, merancang, mendiskusikan, mempresentasikan bahkan memproduksi karya arsitekturnya. Hal ini membuat profesi arsitek mengalami disrupsi dengan berbagai teknologi yang dianggap membantu arsitek namun pelan-pelan bertransformasi menjadi arsitek dengan bantuan sistem kecerdasan buatan (AI), sehingga peran manusia digantikan oleh machine learning atau AI.

Teknologi selalu memiliki dua sisi dalam perkembangannya, menolong manusia juga dapat menghilangkan peran manusia. Namun harus diingat, AI juga dibuat oleh manusia dan belajar dari manusia, karena itu kreativitas manusia menjadi hal terdepan. Apa yang dibuat AI akan dimengerti oleh AI itu sendiri dan manusia tidak perlu berusaha mengerti apa yang AI kerjakan atau bahkan berkompetisi dengan AI. Kreativitas bukan hanya tentang penciptaan oleh Shakespeare atau Einstein atau Affandi. Kreativitas dibentuk dari berbagai kegiatan kreativitas yang sederhana, namun dari hasil dari kreativitas sederhana itu menciptakan kreativitas lain yang lebih dikenal. Manusia dengan kreativitasnya akan mencipta dan terus mencipta.

"The chief enemy of creativity is good sense" (Pablo Picasso).

\section{Daftar Pustaka}

Burry, M. (2011). Scripting culture. New Jersey: Wiley and Sons.

Sautoy, M.D. (2019). The creativity code art and innovation in the age of AI. London: HarperCollins Publishers. 